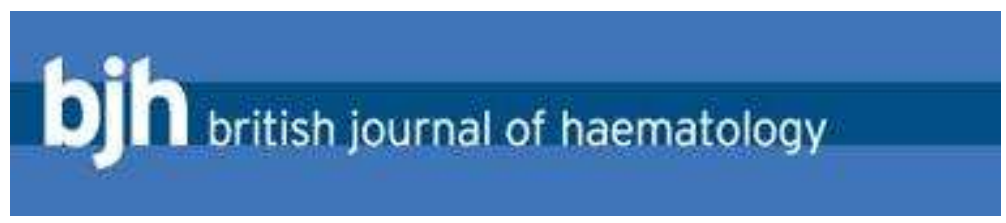

\title{
ASXL1 mutation is associated with poor prognosis and acute transformation in chronic myelomonocytic leukaemia
}

\begin{tabular}{|c|c|}
\hline Journal: & British Journal of Haematology \\
\hline Manuscript ID: & BJH-2010-00989.R1 \\
\hline Manuscript Type: & Ordinary Papers \\
\hline $\begin{array}{r}\text { Date Submitted by the } \\
\text { Author: }\end{array}$ & 09-Jul-2010 \\
\hline Complete List of Authors: & $\begin{array}{l}\text { Gelsi-Boyer, Véronique; Institut Paoli Calmettes, Biopathology; } \\
\text { CRCM, UMR } 891 \text { Inserm, Molecular Oncology } \\
\text { Trouplin, Virginie; CRCM, UMR } 891 \text { Inserm, Molecular Oncology } \\
\text { Roquain, Julien; CRCM, UMR } 891 \text { Inserm, Molecular Oncology } \\
\text { Adelaïde, José; CRCM, UMR } 891 \text { Inserm } \\
\text { Carbuccia, Nadine; CRCM, Molecular Oncology } \\
\text { Esterni, Benjamin; Institut Paoli-Calmettes, Biostatistics } \\
\text { Finetti, Pascal; CRCM, Molecular Oncology } \\
\text { Murati, Anne; CRCM, UMR } 891 \text { Inserm, Molecular Oncology } \\
\text { Arnoulet, Christine; Institut Paoli Calmettes, Biopathology } \\
\text { Zerazhi, Hacène; Centre Hospitalier Général, Médecine Interne } \\
\text { Onco-hématologie } \\
\text { Fezoui, Hacene; Hopital Font Pre, Medecine } \\
\text { Tadrist, Zoulika; Centre Hospitalier Général, Médecine Interne } \\
\text { Onco-hématologie } \\
\text { Nezri, Meyer; CH Martigues, Hematology } \\
\text { CHAFFANET, Max; CRCM, UMR } 891 \text { Inserm, Molecular Oncology } \\
\text { MARIE-jOELLE, MOZZICONACCI; Institut Paoli Calmettes, } \\
\text { Biopathology } \\
\text { Vey, Norbert; Institut Paoli Calmettes, Hematology } \\
\text { Birnbaum, Daniel; Institut Paoli Calmettes, UMR 891; CRCM, UMR } \\
\text { 891 Inserm, Molecular Oncology }\end{array}$ \\
\hline Key Words: & CMML, MUTATIONS, CGH \\
\hline
\end{tabular}

\section{scholarONE"




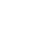

\author{
July 10
}

\begin{abstract}
ASXL1 mutation is associated with poor prognosis and acute transformation in chronic myelomonocytic leukaemia
\end{abstract}

1. Centre de Recherche en Cancérologie de Marseille; Laboratoire d'Oncologie Moléculaire; UMR891 Inserm; Institut Paoli-Calmettes; Marseille, France.

2. Bureau d'études cliniques, Biostatistiques, Institut Paoli-Calmettes, Marseille, France.

3. Université de la Méditerranée Aix-Marseille II, Marseille, France.

4. Département de BioPathologie, Institut Paoli-Calmettes, Marseille, France.

5. Service de Médecine Interne Onco-Hématologie, Centre Hospitalier Général d'Avignon, France.

6. Service d'Onco-Hématologie, Hôpital Font-pré, Centre Hospitalier Intercommunal de Toulon, France. 
7. Service de Médecine Interne Onco-Hématologie, Centre Hospitalier Général de Salon de Provence, France.

8. Service de Médecine Interne, Centre Hospitalier Général, Martigues, France.

9. Département d'Hématologie, Institut Paoli-Calmettes, Marseille, France

${ }^{*}$ Equal contributors.

Corresponding author: Véronique Gelsi-Boyer, UMR891 Inserm, 27 Bd. Leï Roure, 13009 Marseille, France. Tel. 33491758407. Email : gelsiv@marseille.fnclcc.fr

Keywords: array-CGH, ASXL1, chronic myelomonocytic leukemia, mutations, prognosis.

Running title: Gene mutations in CMML 


\section{Summary}

Chronic myelomonocytic leukemia $(\mathrm{CMML})$ is a haematological disease currently classified in the category of myelodysplastic syndromes/myeloproliferative neoplasm (MDS/MPN) because of its dual clinical and biological presentation. The molecular biology of CMML is poorly characterised. We studied a series of $53 \mathrm{CMML}$ samples including 31 cases of myeloproliferative form (MP-CMML) and 22 cases of myelodysplastic forms (MD-CMML) using array-comparative genomic hybridisation $(\mathrm{aCGH})$ and sequencing of 13 candidate genes including $A S X L 1, C B L, F L T 3, I D H 1$, IDH2, JAK2, KRAS, NPM1, NRAS, PTPN11, RUNX1, TET2 and WT1. Mutations in $A S X L 1$ and in the genes associated with proliferation (CBL, FLT3, PTPN11, RAS) were mainly found in MP-CMML cases. Mutations of ASXL1 correlated with an evolution toward an acutely transformed state: all CMMLs that progressed to acute phase were mutated and none of the unmutated patients had evolved to acute leukaemia. The overall survival of $A S X L 1$ mutated patients was lower than that of unmutated patients.

Keywords: chronic myelomonocytic leukaemia, gene mutation, ASXL1, prognosis. 
Chronic myelomonocytic leukaemia $(\mathrm{CMML})$ is a haematopoietic disease currently classified by the WHO organization in a mixed category called MDS/MPN (myelodysplastic syndromes/myeloproliferative neoplasm) (Vardiman, 2002). Despite recent molecular improvements in the classification of myeloid neoplasms, diagnosis of CMML is still based on cytological criteria including persistent peripheral monocytosis greater than $1 \times 10^{9} / \mathrm{L}$, less than $20 \%$ blasts in the blood or bone marrow (BM) and bone marrow dysplasia in one or more myeloid lineage. The only molecular criterium is the absence of $B C R-A B L$ transcript (Bennett et al, 1982, Vardiman, 2002). Because the blast number is a prognostic factor, CMML is divided in two types: type 1 with fewer than $5 \%$ blasts in the blood and $10 \%$ blasts in the bone marrow, and type 2 with between 5 to $19 \%$ in the blood or 10 to19\% in the bone marrow (Vardiman, 2002; Vardiman et al, 2009).

Classification of CMML has always been a matter of debate based on the two distinct clinical presentations: dysplastic with symptomatic complications of cytopenia, and proliferative with splenomegaly or hepatomegaly. In 1994, on the basis of an arbitrary threshold of peripheral leukocyte count (WBC), a dysplastic $(<13$ $\left.\times 10^{9} / \mathrm{L}\right)$ and a proliferative (> $\left.13 \times 10^{9} / \mathrm{L}\right)$ forms have been recognised by the FAB group (Bennett, 1994), which we will call here MD-CMML and MP-CMML, respectively. Until recently, neither biologic nor prognostic data allowed the support of this distinction except that MP-CMML seemed to have more RAS mutations (Padua et al, 1988; Padua et al, 1998). Recently, new molecular alterations have been described in CMML. We and others have showed a high frequency of RUNX1 and TET2 mutations (Gelsi-Boyer et al, 2008; Kosmider et al, 2009b; Kuo et al, 2009). Mutations of TET2 and CBL occur in 50\% (Kosmider et al, 2009b) and 5\% 
(Makishima et al, 2009) of CMML cases, respectively. Recently, we described exon 12 mutations of $A S X L 1$ with a frequency about 44\% (Gelsi-Boyer et al, 2009). Currently, the impact of these alterations remains to be determined and the biological and clinical presentations are still heterogeneous and benefit from opposite therapeutics: cytotoxic in the MP form, haematopoietic growth factors in the MD form.

We propose here a comprehensive study of molecular alterations in a series of 53 CMMLs using genome-wide, high-density array-comparative genomic hybridisation (aCGH) and exon-coding sequencing of 13 candidate genes. We show that $A S X L 1$ mutations are associated with MP-CMML and that MP-CMMLs have overall more alterations. Most importantly, we show that mutations in ASXL1 correlate with acute transformation of CMML and that the overall survival rate is lower in ASXL1 mutated patients than in unmutated patients.

\section{Patients and methods}

\section{Patients and samples}

A series of consecutive bone marrow samples obtained from 53 patients, who all signed an informed consent, were collected. Among these were 31 MP-CMMLs and 22 MD-CMMLs as initially defined by the FAB group with a leukocyte count superior or inferior to $13 \times 10^{9} / \mathrm{L}$, respectively. The median age and leukocytosis were 74 years and $30 \times 10^{9} / \mathrm{L}$ respectively in the MP-CMML group and 76.5 years and $9 \times 10^{9} / L$ respectively in the MD-CMML group. The main clinical and biological data of the 53 samples are presented in Supplementary Table I. Most of the samples (39 cases) were obtained from patients newly diagnosed. Fourteen were 
known for a CMML either in therapeutic abstention (9 cases) or under symptomatic treatment (5 cases). Most patients of the latter group (12/14) were at more of one year after diagnosis. Six patients had received prior chemotherapy or radiotherapy for an independent solid tumour. A normal karyotype was observed in 40 patients (20 MP-CMMLs and 20 MD-CMMLs); a del(20q)(q11q13) was found in 3 patients (2 MPCMMLs and 1 MD-CMML); a trisomy of a commonly affected chromosome $(8,19,21)$ was encountered in 4 MP-CMMLs. One MD-CMML had an 11q inversion, one MPCMML had a t(10;11)(p12;p15) and one MP-CMML had a $t(1 ; 3)(p 36 ; q 21)$. Nucleic acid extraction was done as previously described (Gelsi-Boyer et al, 2008).

\section{Array comparative genomic hybridisation (aCGH)}

aCGH was done on all samples but two (HD-0397, HD-0715). Some of the results have been published on 38 cases (Gelsi-Boyer et al, 2008; Gelsi-Boyer et al, 2009). Genomic imbalances were analysed by aCGH using $244 \mathrm{~K}$ CGH Microarrays (Hu-244A, Agilent Technologies, Massy, France) as previously described (Adélaïde et al 2007; Etienne et al, 2007). Scanning was done with Agilent Autofocus Dynamic Scanner (G2565BA, Agilent Technologies). Data analysis was done as previously described (Murati et al, 2003; Barrett et al 2004,) and visualised with CGH Analytics 3.4 software (Agilent Technologies). Extraction data ( $\log _{2}$ ratio) was done with $\mathrm{CGH}$ analytics while normalised and filtered $\log _{2}$ ratios were obtained from « Feature extraction» software (Agilent Technologies). Copy number changes were characterised as reported (Adélaïde et al, 2007; Etienne et al, 2007).

\section{DNA sequencing}


Polymerase chain reaction (PCR) and direct sequencing were done using standard conditions with gene-specific primers designed to amplify coding sequence of $A S X L 1$ (exon 12), CBL (exons 8, 9), FLT3 (exons 14, 15, 20), IDH1/2 (exon 4), JAK2 (exon 14), K, NRAS (exons 1, 2), NPM1 (exon 12), PTPN11 (exons 3, 11), RUNX1 (exons 1 to 8), TET2 (exons 3 to 11) and WT1 (exons 7, 9) as previously described (Gelsi-Boyer et al, 2008; Gelsi-Boyer et al, 2009, Kosmider et al 2009a, Carbuccia et al, 2010; Kosmider, et al 2009b). Primers are described in Gelsi-Boyer et al. (2008) and Rocquain et al. (2010b). Most PCR amplifications were done in a total volume of $25 \mu \mathrm{l}$ PCR mix containing at least $10 \mathrm{ng}$ template DNA, Taq buffer, $200 \mu \mathrm{mol}$ of each deoxynucleotide triphosphate, 20 pmol of each primer and 1 unit of Hot Star Taq (Qiagen). PCR amplification conditions were as follows: $95^{\circ} \mathrm{C} 10 \mathrm{~min}$; $95^{\circ} \mathrm{C} 30 \mathrm{sec}$, variable temperature $30 \mathrm{sec}, 72^{\circ} \mathrm{C} 45 \mathrm{sec}$ for 30 cycles; $72^{\circ} \mathrm{C} 10 \mathrm{~min}$. PCR products were purified using Millipore plate MSNU030. Two microliters of the purified PCR products were used for sequencing using the Big Dye terminator v1.1 kit (Applied Biosystems). After G50 purification, sequences were loaded on an ABI 3130XL automat (Applied Biosystems). The sequence data files were analysed using the SeqScape software and all mutations were confirmed on an independent PCR product.

\section{Statistical Analysis}

Clinical and biological factors were taken at the time of sampling whose date corresponds to the search for molecular alterations. The different quantitative biological variables were compared by the Student test (t-test) and prevalence of mutations or alterations detected by karyotype or aCGH by the Chi-square test. Overall survival was defined by the time from the date of diagnosis to the date of 
death. Patients still alive were right censored at the date of last contact. "Time-toAML" was defined by the time from the date of sampling to the date of acute transformation. Patients still alive were right censored at the date of last contact. In time-to-AML analysis, deaths occurring before $\mathrm{AML}$ transformation were treated as competing event. To investigate the association between outcome and the different covariates, univariate analysis was done using Log-Rank, Wald, and Gray tests. Cox Proportional Hazard and Fine and Gray models were used in a multivariate approach. Cumulative incidences of AML transformations were estimated by the Prentice method. All statistical tests were two-sided at the $5 \%$ level of significance.

\section{Results}

aCGH profiles of CMML

We established the aCGH profiles of 51 of the 53 CMML cases. Results are summarized in Table I. aCGH revealed alterations that were observed by conventional cytogenetics $(9 / 51)$ except for 3 patients with balanced translocations (HD-0201, HD-0316, HD-0178), and for case HD-0367 with a del(20)(q11q13) for which aCGH did not show a frank deletion at $20 \mathrm{q}$ probably due to the low number of affected cells. For nine cases (17\%) aCGH detected rare and limited losses or gains, not visible on the karyotype. They affected very few genes, as previously described (Gelsi-Boyer et al, 2008; Adélaïde et al, 2010; Rocquain et al, 2010a), including some with known tumour suppressor function and leukaemogenic activity (NF1, RB1 and TET2). In $70 \%$ of cases (36/51) no copy number aberrations were observed. 


\section{Mutations in candidate genes are frequent in CMML}

We studied coding sequences of 13 genes on the 53 cases (Table I). Some results have been previously published (Gelsi-Boyer et al, 2008; Gelsi-Boyer et al, 2009; Kosmider et al, 2009b). In 25 cases (49\%) we found 20 frameshift (including 7 times the same p.Gly646Trpfsx12) and 5 nonsense mutations in ASXL1 exon 12. For three patients (HD-0228, HD-0328, HD-0370), we could demonstrate that the mutation was acquired because the mutation was absent from buccal smear DNA (not shown). CBL exon 8 mutations were found in about $10 \%$ of cases (5/47); one case (HD-0223) had a homozygous mutation. One case (HD-0367) had an internal tandem duplication of $F L T 3$. We found $5 I D H$ mutations in 48 cases (10\%); all were in IDH2 (4 times the same p.Arg140GIn). Seven patients out of the 53 cases (13\%) had a $K$ or NRAS mutation. We previously examined the sequence of exons 3 and 13 of the PTPN11 gene and mutations were found in two cases (Gelsi-Boyer et al, 2008). Twelve out of 53 patients (21\%) were mutated for RUNX1 and $36 \%$ of patients were mutated for TET2. No mutation was found in NPM1, JAK2 and WT1. On the basis of small deletions detected by aCGH and spanning only few genes, we searched for mutations in an additional set of candidate genes: ASXL2, BRAF, CBFB, CTNNB1, KDM3B, KDM6A/UTX, KDM6B, NFIA, PYGO1, SPI1, RAF1, and TET3 but failed to find any mutations (unpublished data) except in one patient (HD-0398) for which a mutation in NFIA exon 2 was found and previously reported (Bernard et al, 2008).

\section{MP- and MD-CMMLs show quantitative differences in molecular alterations}

Genomic alterations detected by conventional cytogenetics or aCGH were different in MP- and MD-CMML (Table I): 15 out of 31 MP-CMMLs and 4 out of 22 
MD-CMMLs showed alterations. MP-CMMLs had more genomic alterations than MDCMMLs $(p=0.049)$.

We compared the prevalence of the mutated genes in MP and MD-CMML. Nineteen of the 25 ASXL1 mutations were found in 30 MP-CMMLs vs 6 in 22 MDCMMLs. Mutations in ASXL1 but not in RUNX1 or TET2 were more frequent in MP than in MD-CMMLs $(p=0.03)$ (Table I). No difference was observed between the two forms for $C B L, F L T 3, I D H 1 / 2, P T P N 11, R A S, R U N X 1$ or TET2. No RAS pathway mutation (RAS and PTPN11) was observed in MD-CMMLs. Mutations in proliferationassociated genes CBL, FLT3, KRAS, NRAS and PTPN11 were mutually exclusive and taken as a whole significantly associated with MP-CMML (14/123 versus 1/91; $\mathrm{p}=0.008$ ). Overall, the number of mutations ( $A S X L 1$ and proliferation genes) was higher in MP than in MD-CMMLs $(p=0.018)$.

Altogether, molecular events (mutations and genomic alterations) were more frequent in MP-CMMLs (69/273 events) than in MD-CMMLs (26/172) $(p=0.0018)$.

Correlations between ASXL1 mutation and clinical and biological features in CMML

The main clinical and biological features of 51 CMML cases were examined with respect to $A S X L 1$ mutations (Table II). The presence of an $A S X L 1$ mutation was associated with higher WBC $\left(30 \times 10^{9} / \mathrm{L}\right.$ vs $\left.15 \times 10^{9} / \mathrm{L}\right)(\mathrm{p}=0.006)$, higher blood $(p=0.005)$ and bone marrow monocytosis $(p=0.04)$ and with lower level of blood haemoglobin $(p=0.03)$. No difference was noted in mean cell volume, blood count of neutrophils and platelets, or bone marrow blasts. In MP-CMMLs, ASXL1 mutation correlated with a lower level of haemoglobin $(p=0.03)$ and platelet count $(p=0.002)$ 
and with a higher monocytosis $(\mathrm{p}=0.04)$. In MD-CMMLs, no correlations with $A S X L 1$ mutation were observed.

Among ASXL1 mutated cases (25/51), eleven (9 MP and 2 MD) had evolved to acute transformation (Table II). For one case (HD-0398) DNA of the acute phase was available; we looked for the $A S X L 1$ mutation and found the same alteration (not shown). In contrast, no acute transformation was observed in the unmutated cases. In other words, all transformed cases had an $A S X L 1$ mutation but not all $A S X L 1$ mutated cases had progressed to AML. ASXL1 mutation and acute transformation were correlated $(p=0.0005)$. Patient HD-0316 had progressed to acute phase but was not included in the 51 patients since we could not determine the ASXL1 status because of lack of material at either stage.

Overall survival (median follow-up of 29.5 months) was analysed for the 53 patients. Median overall survival was 27.6 months (Fig 1A). ASXL1 status could be determined at the time of diagnosis for 51 patients. Kaplan-Meier analysis showed a lower overall survival rate in the $A S X L 1$ mutated patients (Fig 1B). With respect to MP/MD form, only a trend to a better survival of the MD patients was observed (not shown). Within MP-CMML patients, cases mutated for ASXL1 had a poorer survival than the unmutated cases (not shown). We determined the cumulative incidence of AML (Fig 1C) and observed that all the patients who developed AML did so within two years and that $A S X L 1$ mutation had a strong impact on AML incidence (Fig 1D). We did the same analysis for TET2 mutational status. In contrast to ASXL1, TET2 had no impact on overall survival (not shown). Given the low number of events for the other genes we did not look for any other clinical or biological correlation.

Univariate analysis of time-to-AML was done on 50 patients using as variables ASXL1 and TET2 mutational status and MP/MD form, monocytosis, blast count in 
bone marrow, anemia, and CMML1/2 type. The following variables showed significance: ASXL1 status ( $\mathrm{p}=0.0002 ; 24$-months incidence: 0.48 , confidence interval 95: [0.26-0.71]), monocytosis in peripheral blood $(p=0.042 ; 24-m o n t h s$ incidence: 0.25 , confidence interval 95: [0.12-0.38]; hazard ratio: 1.05 , confidence interval 95: [1-1.09]), blast count $(p=0.0011 ; 24$-months incidence: 0.25 , confidence interval: [0.12-0.38]; hazard ratio: 1.18, confidence interval: [1.07-1.3]) and CMML1/2 ( $p=0.014$; CMML1 24-months incidence: 0.16, confidence interval: [0.04-0.28], hazard ratio: 1; CMML2 24-months incidence: 0.58, confidence interval: [0.23-0.93], hazard ratio: 3.96, confidence interval: [1.34-11.7]). A multivariate analysis of time-toAML was done using Cox regression model and the same variables. Only the ASXL1 status retained significant prognostic impact $(\mathrm{p}<0.0001)$. Thus, in CMML, ASXL1 mutation is an unfavourable prognostic factor for overall survival and progression to AML.

\section{Discussion}

We established the genomic profiles of a series of 53 CMMLs by using aCGH and sequencing of 13 candidate genes.

ASXL1 is the most frequently mutated gene in CMML

In more than two-thirds of cases aCGH profiles did not show any copy number aberrations. In few cases, small copy number aberrations were indicative of genes known (NF1, RB1, TET2) or suspected (SH3KPB1, RAD21) (Adélaïde et al, 2010; 
Rocquain et al, 2010a) to be involved in leukaemogenesis. MP-CMMLs had more genomic alterations than MD-CMMLs.

We studied 13 candidate genes. We classified these genes into three groups. The first group comprised five known and potential tumour suppressors and transcription factors, the second group six genes associated with kinase activity, signalling pathways and proliferation, and the third group the two IDH genes. Hypothetically, CMML could result from a combination of mutation(s) in each of these groups, and perhaps more yet-to-be discovered mutations. Overall, mutations of ASXL1, RUNX1 and TET2 were prominent in particular in MP-CMMLs but the difference between the two forms was not statistically significant for the three genes taken as a whole $(p=0.19)$. Mutations in these three genes were not mutually exclusive. This is in contrast to what we observed in myelodysplastic syndromes (MDS) and acute myeloid leukaemia where RUNX1 and TET2 mutations were mutually exclusive but could each be associated with ASXL1 mutations (Rocquain et al., 2010b). We have no explanation for this observation. ASXL1 mutations are found in all myeloid neoplasms (Carbuccia et al, 2009; Gelsi-Boyer et al, 2009; Carbuccia et al, 2010; Kosmider et al, 2009a; Boultwood et al, 2010a; Boultwood et al, 2010b; Sugimoto et al, 2010; Tefferi, 2010). In the present study ASXL1 appeared as the most frequently mutated gene in CMML, as it is in MDSs (Boultwood et al, 2010a; Rocquain et al, 2010b). In MDSs, ASXL1 mutations are found in high-risk cases.

As previously observed (Gelsi-Boyer et al, 2008) mutations in the second group of "proliferation" genes were mutually exclusive. The frequency of mutations of $C B L$ was in the range of what was observed recently (Makishima et al, 2009). With two exceptions (a CBL mutation and an NF1 deletion detected by aCGH), mutations in these genes were a hallmark of MP-CMML and may explain the proliferative 
features of this form. In agreement, it has recently been shown that JAK2 mutations are associated with MP-CMML (Ricci et al, 2010). However, in our series we did not find any JAK2 mutation. Overall, the number of mutations ( $A S X L 1$ and proliferation genes) was higher in MP-CMML than in MD-CMML. This is a molecular basis to the separation of $C M M L$ in $M P$ and $M D$ forms initially defined by the $F A B$ group. However, the equal number of mutations of $R U N X 1$ and TET2 in both forms suggests a common mechanism of oncogenesis.

ASXL1 mutation is associated with poor prognosis and acute transformation of CMML

The MP and MD classification may have a molecular basis (Gelsi-Boyer et al, 2007; this work) but had no significant impact on prognosis in our series. Several studies have similarly found that this classification does not by itself offer enough prognostic information (Germing et al, 1998; Nosslinger et al, 2001; GonzalezMedina et al, 2002). We have here shown that, in contrast, $A S X L 1$ mutation is associated with both poor overall survival and acute transformation. In our series, no unmutated cases had evolved to acute phase whereas the cases that had progressed to acute leukaemia were all mutated (except for one case for which we could not determine the $A S X L 1$ status). A multivariate analysis of time-to-AML including $A S X L 1$ mutation and other factors revealed that only $A S X L 1$ status has significant impact. However, ASXL1 status was not significant in multivariate analysis of overall survival (not shown), perhaps because of the limited number of cases or the existence of confounding factors such as deaths by other causes. Some mutated cases had not progressed to acute phase. This may be because patients had died before experiencing acute leukaemia. This may have been the case for patients HD- 
0230 and HD-0660, whose $A S X L 1$ mutated CMML progressed from CMML1 to CMML2. For mutated patients still alive it could be a question of time. If this were the case $A S X L 1$ mutation could be used to predict the risk of progression of CMML to acute leukaemia. In contrast, TET2 mutations had no impact. A previous study had found prognostic impact of TET2 mutation but only in CMML1 (Kosmider et al, 2009b).

ASXL1 mutation is associated with aggressive forms in other myeloid disorders, including high-risk MDSs, primitive myelofibrosis (Carbuccia et al, 2009), secondary acute myeloid leukaemias (Carbuccia et al, 2010). If confirmed on a larger series the data would endow $A S X L 1$ with such a prognostic value that its mutational status may be systematically determined in hospital setting and that the management of patients with mutation may be adapted. It could also be interesting to classify CMMLs studied in clinical trials according to $A S X L 1$ status.

\section{Author contributions}

AM, CA, HZ HF, ZT, MN, MJM, and NV selected the cases, and provided and reviewed the clinical and biological data. JA and MC generated and analyzed the aCGH data. VT, JR, and NC generated and analyzed the sequencing data. BE and PF did the statistical analyses. VGB and DB supervised the study and wrote the manuscript. All authors approved the study and the manuscript.

\section{Acknowledgements}

We are grateful to the patients who accepted to participate in this study. The 
work was supported by Inserm and Institut Paoli-Calmettes.

\section{References}

Adélaïde, J., Finetti, P., Bekhouche, I., Repellini, L., Geneix, J., Sircoulomb, F., Charafe-Jauffret, E., Cervera, N., Desplans, J., Parzy, D., Schoenmakers, E., Viens, P., Jacquemier, J., Birnbaum, D., Bertucci, F. \& Chaffanet, M. (2007) Integrated profiling of basal and luminal breast cancers. Cancer Res, 67, $11565-11575$.

Adélaïde, J., Rocquain, J., Gelsi-Boyer, V., Carbucci, N., Birnbaum, D.J., Mozziconacci, MJ., Vey, N., Birnbaum, D. \& Chaffanet, M. (2010) Gain of CBL-interacting protein: a possible alternative to $\mathrm{CBL}$ mutations in myelodysplastic syndromes and chronic myelomonocytic leukemia.

Leukemia, 24, in press.

Barrett, M.T., Scheffer, A., Ben-Dor, A., Sampas, N., Lipson, D., Kincaid, R., Tsang, P., Curry, B., Baird, K., Meltzer, P.S., Yakhini, Z., Bruhn, L. \& Laderman, S. (2004) Comparative genomic hybridization using oligonucleotide microarrays and total genomic DNA. Proc Natl Acad Sci U S A, 101, 17765-17770.

Bennett, J.M., Catovsky, D., Daniel, M.T., Flandrin, G., Galton, D.A., Gralnick, H.R. \& Sultan, C. (1982) Proposals for the classification of the myelodysplastic syndromes. Br J Haematol, 51, 189-199.

Bennett JM, C.D., Daniel MT, et al (1994) The chronic myeloid leukaemias: guidelines for distinguishing chronic granulocytic, atypical chronic myeloid, and chronic myelomonocytic leukaemia. Proposals by the French-AmericanBritish Cooperative Leukaemia Group. Br J Haematol, 84, 746-754.

Bernard, F., Gelsi-Boyer, V., Murati, A., Giraudier, S., Trouplin, V., Adélaïde, J., Rey, J., Olschwang, S., Vainchenker, W., Chaffanet, M., Vey, N., Mozziconacci, M.J. \& Birnbaum, D. (2008) Alterations of NFIA in chronic malignant myeloid diseases. Leukemia.

Boultwood, J., Perry, J., Pellagatti, A., Fernandez-Mercado, M., FernandezSantamaria, C., Calasanz, M.J., Larrayoz, M.J., Garcia-Delgado, M., Giagounidis, A., Malcovati, L., Della Porta, M.G., Jadersten, M., Killick, S., Hellstrom-Lindberg, E., Cazzola, M. \& Wainscoat, J.S. Frequent mutation of the polycomb-associated gene ASXL1 in the myelodysplastic syndromes and in acute myeloid leukemia. Leukemia, 24, 1062-1065.

Boultwood, J., Perry, J., Zaman, R., Fernandez-Santamaria, C., Littlewood, T., Kusec, R., Pellagatti, A., Wang, L., Clark, R.E. \& Wainscoat, J.S. High-density single nucleotide polymorphism array analysis and ASXL1 gene mutation screening in chronic myeloid leukemia during disease progression. Leukemia, 24, 1139-1145.

Carbuccia, N., Murati, A., Trouplin, V., Brecqueville, M., Adélaïde, J., Rey, J., Vainchenker, W., Bernard, O.A., Chaffanet, M., Vey, N., Birnbaum, D. \& Mozziconacci, M.J. (2009) Mutations of ASXL1 gene in myeloproliferative neoplasms. Leukemia, 23, 2183-2186.

Carbuccia, N., Trouplin, V., Gelsi-Boyer, V., Murati, A., Rocquain, J., Adélaïde, J., Olschwang, S., Xerri, L., Vey, N., Chaffanet, M., Birnbaum, D. \& Mozziconacci, 
M.J. Mutual exclusion of ASXL1 and NPM1 mutations in a series of acute myeloid leukemias. Leukemia, 24, 469-473.

Etienne, A., Carbuccia, N., Adélaïde, J., Bekhouche, I., Remy, V., Sohn, C., Sainty, D., Gastaut, J.A., Olschwang, S., Birnbaum, D., Mozziconacci, M.J. \& Chaffanet, M. (2007) Rearrangements involving $12 q$ in myeloproliferative disorders: possible role of HMGA2 and SOCS2 genes. Cancer Genet Cytogenet, 176, 80-88.

Gelsi-Boyer, V., Cervera, N., Bertucci, F., Trouplin, V., Remy, V., Olschwang, S., Chaffanet, M., Vey, N., Mozziconacci, M.J. \& Birnbaum, D. (2007) Gene expression profiling separates chronic myelomonocytic leukemia in two molecular subtypes. Leukemia, 21, 2359-2362.

Gelsi-Boyer, V., Trouplin, V., Adélaïde, J., Aceto, N., Remy, V., Pinson, S., Houdayer, C., Arnoulet, C., Sainty, D., Bentires-Alj, M., Olschwang, S., Vey, N., Mozziconacci, M.J., Birnbaum, D. \& Chaffanet, M. (2008) Genome profiling of chronic myelomonocytic leukemia: frequent alterations of RAS and RUNX1 genes. BMC Cancer, 8, 299-315.

Gelsi-Boyer, V., Trouplin, V., Adélaïde, J., Bonansea, J., Cervera, N., Carbuccia, N., Lagarde, A., Prebet, T., Nezri, M., Sainty, D., Olschwang, S., Xerri, L., Chaffanet, M., Mozziconacci, M.J., Vey, N. \& Birnbaum, D. (2009) Mutations of polycomb-associated gene ASXL1 in myelodysplastic syndromes and chronic myelomonocytic leukaemia. Br J Haematol, 145, 788-800.

Germing U, G.N., Minning H, Heyll A, Aul C. (1998) Problems in the classification of CMML--dysplastic versus proliferative type. Leuk Res, 22, 871-878.

Germing U, S.C., Knipp S, Kuendgen A, Giagounidis A, Hildebrandt B et al. (2007) Chronic myelomonocytic leukemia in the light of the WHO proposals. haematologica, 92, 974-977.

Gonzalez-Medina I, B.J., Torrequebrada A, Lopez A, Vallespi T \& Massague I. (2002) Two groups of chronic myelomonocytic leukaemia: myelodysplastic and myeloproliferative. Prognostic implications in a series of a single center. Leuk Res, 26, 821-824.

Kosmider, O., Gelsi-Boyer, V., Cheok, M., Grabar, S., Della-Valle, V., Picard, F., Viguie, F., Quesnel, B., Beyne-Rauzy, O., Solary, E., Vey, N., Hunault-Berger, M., Fenaux, P., Mansat-De Mas, V., Delabesse, E., Guardiola, P., Lacombe, C., Vainchenker, W., Preudhomme, C., Dreyfus, F., Bernard, O.A., Birnbaum, D. \& Fontenay, M. (2009a) TET2 mutation is an independent favorable prognostic factor in myelodysplastic syndromes (MDSs). Blood, 114, 32853291.

Kosmider, O., Gelsi-Boyer, V., Ciudad, M., Racoeur, C., Jooste, V., Vey, N., Quesnel, B., Fenaux, P., Bastie, J.N., Beyne-Rauzy, O., Stamatoulas, A., Dreyfus, F., Ifrah, N., de Botton, S., Vainchenker, W., Bernard, O.A., Birnbaum, D., Fontenay, M. \& Solary, E. (2009b) TET2 gene mutation is a frequent and adverse event in chronic myelomonocytic leukemia. haematologica, 94, 1676-1681.

Kosmider, O., Gelsi-Boyer, V., Slama, L., Dreyfus, F., Beyne-Rauzy, O., Quesnel, B., Hunault-Berger, M., Slama, B., Vey, N., Lacombe, C., Solary, E., Birnbaum, D., Bernard, O.A. \& Fontenay, M. Mutations of IDH1 and IDH2 genes in early and accelerated phases of myelodysplastic syndromes and MDS/myeloproliferative neoplasms. Leukemia, 24, 1094-1096.

Kuo, M.C., Liang, D.C., Huang, C.F., Shih, Y.S., Wu, J.H., Lin, T.L. \& Shih, L.Y. (2009) RUNX1 mutations are frequent in chronic myelomonocytic leukemia 
and mutations at the C-terminal region might predict acute myeloid leukemia transformation. Leukemia, 23, 1426-1431.

Makishima, H., Cazzolli, H., Szpurka, H., Dunbar, A., Tiu, R., Huh, J., Muramatsu, H., O'Keefe, C., Hsi, E., Paquette, R.L., Kojima, S., List, A.F., Sekeres, M.A., McDevitt, M.A. \& Maciejewski, J.P. (2009) Mutations of e3 ubiquitin ligase cbl family members constitute a novel common pathogenic lesion in myeloid malignancies. J Clin Oncol, 27, 6109-6116.

Murati, A., Adélaïde, J., Popovici, C., Mozziconacci, M.J., Arnoulet, C., LafagePochitaloff, M., Sainty, D., Birnbaum, D. \& Chaffanet, M. (2003) A further case of acute myelomonocytic leukemia with inv(8) chromosomal rearrangement and MOZ-NCOA2 gene fusion. Int J Mol Med, 12, 423-428.

Nosslinger, T., Reisner, R., Grüner, H., Tüchler, H., Nowotny, H., Pittermann, E. \& Pfeilstöcker M. (2001) Dysplastic versus proliferative CMML--a retrospective analysis of 91 patients from a single institution. Leuk Res, 25, 741-747.

Onida, F. (2002) pronostics factors in chronic myelomonocytic leukemia: a retrospective analysis of 213 patients. Blood, 99, 840-849.

Padua, R.A., Carter, G., Hughes, D., Gow, J., Farr, C., Oscier, D., McCormick, F., Jacobs, A. (1988) RAS mutations in myelodysplasia detected by amplification, oligonucleotide hybridization, and transformation. Leukemia, 2, 503-510.

Padua, R.A., Guinn, B.A., Al-Sabah, A.I., Smith, M., Taylor, C., Pettersson, T., Ridge, S., Carter, G., White, D., Oscier, D., Chevret, S. \& West, R. (1998) RAS, FMS and p53 mutations and poor clinical outcome in myelodysplasias: a 10-year follow-up. Leukemia, 12, 887-892.

Ricci, C., Fermo, E., Corti, S., Molteni, M., Faricciotti, A., Cortelezzi, A., Lambertenghi Deliliers, G., Beran, M. \& Onida, F. RAS mutations contribute to evolution of chronic myelomonocytic leukemia to the proliferative variant. Clin Cancer Res, 16, 2246-2256.

Rocquain, J., Gelsi-Boyer, V., Adélaïde, J., Murati, A., Carbuccia, N., Vey, N., Mozziconacci, MJ., Birnbaum, D. \& Chaffanet, M. (2010a) Alteration of cohesin genes in myeloid diseases. Am J Hematol, in press.

Rocquain, J., Carbuccia, N., Trouplin, V., Raynaud, S., Murati, A., Nezri, M., Tadrist, Z., Olschwang, S., Vey, N., Birnbaum, D., Gelsi-Boyer, V.\& Mozziconacci, MJ. (2010b) Combined mutations of ASXL1, CBL, FLT3, IDH1, IDH2, JAK2, KRAS, NPM1, NRAS, RUNX1, TET2 and WT1 genes in myelodysplastic syndromes and acute myeloid leukemias. BMC Cancer, in press.

Sugimoto, Y., Muramatsu, H., Makishima, H., Prince, C., Jankowska, A.M., Yoshida, N., Xu, Y., Nishio, N., Hama, A., Yagasaki, H., Takahashi, Y., Kato, K., Manabe, A., Kojima, S. \& Maciejewski, J.P. (2010) Spectrum of molecular defects in juvenile myelomonocytic leukaemia includes ASXL1 mutations. $\mathrm{Br} J$ Haematol, 150, 83-87.

Tefferi, A. (2010) Novel mutations and their functional and clinical relevance in myeloproliferative neoplasms: JAK2, MPL, TET2, ASXL1, CBL, IDH and IKZF1. Leukemia, 24, 1128-1138.

Vardiman J-W, H.N.-L. \& Brunning R-D (2002) the world health classification (WHO) of myeloid neoplasms, Blood, 100, 2292-2302.

Vardiman, J.W., Thiele, J., Arber, D.A., Brunning, R.D., Borowitz, M.J., Porwit, A., Harris, N.L., Le Beau, M.M., Hellstrom-Lindberg, E., Tefferi, A. \& Bloomfield, C.D. (2009) The 2008 revision of the WHO classification of myeloid neoplasms and acute leukemia: rationale and important changes. Blood, 114, 937-951. 
Table I. Mutations of candidate genes in a series of CMML.

\begin{tabular}{|c|c|c|c|c|c|c|c|c|c|c|c|c|c|c|c|c|c|c|}
\hline case & $\begin{array}{l}\underbrace{S e x A g e}_{S} \\
\text { (years) }\end{array}$ & Diagnosis & $\begin{array}{c}\text { Runx1 } \\
\text { (exons } 1-8)\end{array}$ & $\begin{array}{c}\mathrm{T} \in \mathrm{T} 2 \\
\text { (exons } 3-11)\end{array}$ & $\begin{array}{l}\text { ASXL1 } \\
(\operatorname{exon} 12)\end{array}$ & $\begin{array}{l}\text { MPMM1 } \\
\text { (exon 12) }\end{array}$ & $\begin{array}{c}w 17 \\
(\text { exons } 7,9)\end{array}$ & $\begin{array}{c}c \text { cbL } \\
\text { (exons 8,9) }\end{array}$ & $\begin{array}{c}\text { FLT3 } \\
\text { ITOTKK }\end{array}$ & $\begin{array}{c}\text { JAK2 } \\
\text { (VVG1F) }\end{array}$ & $\begin{array}{c}\text { KRAS } \\
\text { (exons } 1,2)\end{array}$ & $\begin{array}{c}\text { NRAS } \\
\text { (exons } 1,2)\end{array}$ & 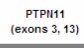 & $\begin{array}{l}\text { IOH1 } \\
(\text { (exon 4) }\end{array}$ & $\begin{array}{c}\text { I0H2 } \\
\text { (exon } 4)\end{array}$ & 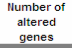 & Karyotype & асGH \\
\hline D.0176 & M42 & MP-CMML1 & no & no & no & no & no & no & no & no & no & no & no & no & no & 0 & $46 \times 1[20]$ & gain 7221 (AHR) X922 \\
\hline HD. 0182 & $F / 74$ & MP-CMML1 & no & no & no & no & no & no & no & no & no & $0.041248 \mathrm{sp}$ & no & no & no & 1 & $45, X,-x>0[20]$ & $\cos x$ \\
\hline HD-2200 & M71 & MP-CMML1 & no & no & no & no & no & no & no & no & PAAl160Val & no & no & no & no & 1 & $46, X[120]$ & no CNA \\
\hline HD. 02201 & M/87 & MP.CMML1 & no & no & 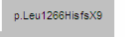 & no & no & no & no & no & $p=$ & pAlabs7oy & no & no & no & 2 & 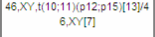 & no c NAa \\
\hline HD.0223 & M/85 & MP-CMML1 & no & solicing detetect & pargy 1083x & no & no & p. Phesen18ser (hom) & no & no & no & no & nd & no & no & 3 & $46, \times[202]$ & 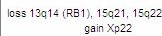 \\
\hline HD.0228 & M70 & MP-CMML1 & no & p. Trpp 198x & p. Thr836Leuts X2 (no) & no & no & no & no & no & p.eyryser & no & no & no & no & 3 & $46, \times[20]$ & 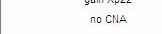 \\
\hline HD.0229 & M/87 & MP-CMML2 & no & p. $\operatorname{cin} 1101 x$ & no & no & no & no & no & no & no & no & nа & no & no & 1 & $46 \times \times[20]$ & no o NA \\
\hline HD. 0257 & $F / 71$ & MP.CMML1 & no & no & no & no & no & no & no & no & no & no & na & no & pargit 1006n & 1 & $46, x<201$ & no c NNA \\
\hline HD-0272 & $F / 79$ & MP-CMML1 & no & 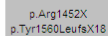 & 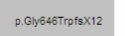 & no & no & no & no & no & no & D. Gy13asp & na & no & no & 3 & $46 \times \times(202]$ & no crla \\
\hline HD.0273 & M76 & MP-CMML1 & no & p.Gy $1361 \mathrm{ser}$ & 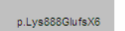 & no & no & no & no & no & no & no & nа & no & p.Arg1 1006in & 3 & $46 \times 1[20]$ & no CNA \\
\hline HD-0316 & 11165 & МР-СМML1 & p. Prota25Leu & па & na & no & па & na & na & no & no & no & DASBg TITY & nа & na & $=2$ & $46 \times x \times[20]$ & 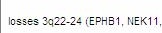 \\
\hline HD.0318 & m/69 & MP-CMML1 & parg166x & no & p. $\operatorname{cin} 786 x$ & na & na & na & па & no & no & no & no & na & па & ${ }^{2}$ & $46, X, y, d e(20)(911913) / 20]$ & loss 20a11-913 \\
\hline HD.0320 & $F / 74$ & MP-сMML2 & splicing defect & p.Argat 100.X & 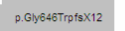 & no & no & no & no & no & no & no & pAatz27Tr & no & no & 4 & $47, x,-8200]$ & tris \\
\hline нD.0321 & M/55 & MP-CMML2 & DArg168x & no & 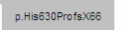 & no & no & па & no & no & no & no & no & no & no & 2 & $46, X[20]$ & loss 32023 GLLB1, C. \\
\hline HD.0322 & $\mathrm{F} / 61$ & MP-CMML1 & no & no & no & no & no & no & no & no & no & no & no & no & no & 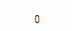 & $46 \times \times X 200]$ & no o N A \\
\hline Hก.-1237 & $F / 72$ & мР-гмMи1 1 & $0.7 y 3777$ eurs 322 & 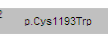 & 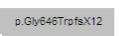 & nn & nn & no & nn & no & no & nam124an & no & no & no & 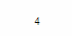 & 47 XXX:spos] & se $70+110$ \\
\hline HD-0366 & M78 & MP-CMML1 & no & no & 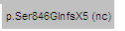 & na & па & па & na & no & no & no & no & na & па & 1 & $46, X[120]$ & nо СNA \\
\hline HD.0367 & $F 70$ & MP-CMML2 & no & no & no & no & no & no & $\pi \mathrm{D}$ & no & no & no & no & no & no & 1 & 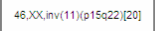 & no CNA \\
\hline HD. 0370 & M70 & MP-CMML2 & no & no & 1.Thr1271Lys ss 10 (nc & no & no & no & no & no & no & no & no & no & no & 1 & $46, X[200]$ & no C $\mathrm{CNA}$ \\
\hline HD.0376 & F/65 & MP-CMML2 & no & no & no & no & no & no & no & no & no & no & no & no & no & 。 & 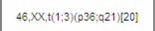 & nо СNA \\
\hline нD.0397 & $F / 71$ & MP-CMML1 & no & no & no & no & no & no & no & no & no & no & па & no & no & 。 & $46 \times \times 2020$ & na \\
\hline HD.0398 & M/62 & MP-CMML1 & no & no & p. Gly 646 Trpts 12 & no & no & no & no & no & no & no & па & no & no & 1 & $47, X Y,+19[177 / 46, X Y[3]$ & trii19 \\
\hline HD. 0399 & M74 & MP-CMML1 & p.Sertifleu & no & 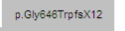 & no & no & p. Cys $396 \mathrm{Tyr}$ & no & no & no & no & no & no & no & 3 & $46, X[20]$ & no cNa \\
\hline HD.0404 & м/8 & MP-CMML2 & p.Arg201x & PAABn158111esX17 & 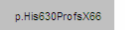 & no & no & no & no & no & no & no & na & no & no & 3 & $47, X Y,+21[20]$ & tri21 \\
\hline HD.0485 & M/63 & MP. CMML 2 & p.Arg320x & p.Leu1252pro & 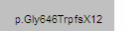 & no & no & no & no & no & no & no & na & no & no & 3 & ${ }_{46, X X Y 20]}$ & no CNA \\
\hline HD.0627 & $F / 87$ & MP-сMML1 & no & no & p.Arg1008x & no & no & 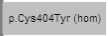 & no & no & no & no & па & no & no & 2 & 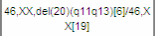 & no CNA \\
\hline нD.0669 & м/8в & MP-CMML1 & no & no & 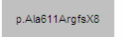 & no & no & no & no & no & no & no & na & no & no & 1 & $46 \times \times[202]$ & no onla \\
\hline HD.0671 & $F / 71$ & MP.СMML1 & D.tyen 10arg & no & p. Tyrsentx & no & no & no & no & no & no & no & na & no & no & $=2$ & $47, X X+19[8] 2466, X X[12]$ & Los 17911 (NF1). \\
\hline HD. 0707 & M/85 & MP.CMML1 & no & no & no & no & no & D. TYMr37 His & no & no & no & no & па & no & no & 1 & $46 \times x \times[20]$ & no CNA \\
\hline HD.0715 & w69 & MP-CMML-1 & no & no & no & no & no & no & no & no & no & no & па & no & no & 。 & $46 \times \times(202]$ & na \\
\hline HD-0723 & m83 & MP-СMМL1 & no & no & p. $1212131 \operatorname{lef} \times x \times 3$ & no & no & no & no & no & no & p.Gy12val & na & no & parglatocin & 3 & $46 \times \times[202]$ & no CNA \\
\hline HD.0178 & M/88 & MD-сMML1 & no & no & no & no & no & no & no & no & no & no & no & no & parglat tocin & 1 & 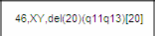 & Ioss 13914 (RB1), 209 \\
\hline HD.0197 & M/59 & MD-CMML1 & p.Arg320x & no & no & na & па & na & na & no & no & no & no & na & na & 1 & ${ }_{46 \times X \times 1200]}$ & no chla \\
\hline HD-02008 & 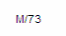 & мо-смицг & no & verevion & paspotsousast & 10 & no & 10 & 100 & no & no & 10 & na & "10 & valyitzays & . & $40, \times 1200]$ & 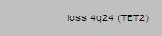 \\
\hline HD.0230 & M/83 & MD.CMML1 & no & no & 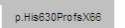 & no & no & no & no & no & no & no & 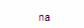 & no & no & 1 & $46 \times 1 \times 1200]$ & no CNA \\
\hline HD-0242 & $F / 82$ & MD.CN & no & no & no & no & 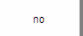 & no & no & no & no & no & 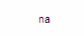 & no & no & 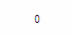 & $46, \times[25]$ & no o NNa \\
\hline HD. 0254 & $F / 83$ & MD-CMML2 & no & no & no & no & no & no & no & no & no & no & па & no & no & 。 & 46,XX200] & Loss 1791 (NF1) \\
\hline HD.0271 & $F / 82$ & MD-CMML1 & no & no & 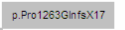 & no & no & no & no & no & no & no & па & no & no & 1 & $46, \times<201$ & no o N Na \\
\hline HD.0280 & w78 & MD-Сl & no & p. Serr1 189vats $\times 37$ & no & no & no & no & no & no & no & no & па & no & no & 1 & 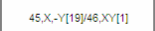 & $\operatorname{loss} Y$ \\
\hline HD-.0328 & M/73 & MD.CN & no & p. Gys5shasp (hom) & p.G1Y646Trpts X12 & no & no & p. Cyy $4004 \mathrm{yr}$ & no & no & no & no & no & no & no & 3 & $46 \times \times[20]$ & nо C CNA \\
\hline HD.0330 & M76 & МD-смицL1 & p. Giy500.intsx 4 & na & na & na & na & na & na & no & no & no & no & na & na & 1 & $46 \times \times[201]$ & no criat \\
\hline HD-0355 & M/65 & MD-CMML1 & no & p.cys $1289 \mathrm{Ph}$. & no & no & no & no & no & no & no & no & no & no & no & 1 & $46 \times \times 120]$ & nо CNA \\
\hline HD.0372 & m/60 & MD-CMML1 & no & no & no & no & no & no & no & no & no & no & no & no & no & 。 & ${ }_{46 \times X \times 120]}$ & no cha \\
\hline HD.-0380 & $F / 82$ & MD-CMML1 & no & D. Ginititax & no & no & no & no & no & no & no & no & no & no & no & 1 & $46, \times(200]$ & nо СNA \\
\hline HD.0388 & $F / 1$ & MD-cMML1 & p. Meter33le & D.Leu 72 21 Pretex $x=8$ & no & no & no & no & no & no & no & no & па & no & no & 2 & 46.XXX20] & no c CNA \\
\hline HD-0396 & M70 & MD-cMML-1 & no & p.Serersax & no & no & no & no & no & no & no & no & na & no & no & 1 & $46 \times 1 / 20]$ & no CNA \\
\hline HD-0638 & $F / 68$ & МD-сминL1 & no & 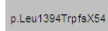 & & no & no & no & no & no & no & no & па & 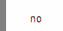 & no & 1 & $46, \times x[20]$ & nо C CNA \\
\hline HD.0660 & мво & MD-CMI & no & no & a.trgasesx & no & no & no & no & no & no & no & nа & no & no & 1 & $46, \times 1200]$ & no CNA \\
\hline HD.0703 & $w 74$ & WD-CII & no & no & no & no & no & no & no & no & no & no & na & no & no & 。 & $46, \times$ & no ond \\
\hline HD- 07 & w/79 & MD & no & p. $\operatorname{cin} 649 x$ & no & no & no & no & no & no & no & no & па & no & no & 1 & $46, \times 1[201]$ & no CNA \\
\hline HD. 0712 & M/41 & MD.CMML1 & no & no & no & no & no & no & no & no & no & no & na & no & no & 0 & $46 \times 1 / 202]$ & no orlat \\
\hline HD. -0743 & W68 & мо-смич1 & no & no & 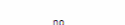 & no & no & no & no & no & no & no & $\mathrm{na}$ & no & no & 0 & $46 \times x \times 1201$ & no ond \\
\hline HD. 0755 & M/46 & мо-ссиич1 & no & 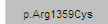 & 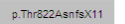 & no & no & no & no & no & no & 10 & na & no & no & 2 & $46, X[20]$ & no chis \\
\hline
\end{tabular}

Samples are separated according to the white blood cell count: MP-CMML with WBC $>13 \times 10^{9} / \mathrm{L}$ and MD-CMML with WBC $<13 \times 10^{9} / \mathrm{L}$.

hom: homozygous; nc : verified as not constitutional

na: non available 


\begin{tabular}{|c|c|c|c|c|}
\hline CMML & $\begin{array}{l}\text { Number of } \\
\text { patients }\end{array}$ & ASXL1 mutated & ASXL1 unmutated & p value \\
\hline Sex ratio & 51 & 3.16 & 1.27 & 0.23 \\
\hline Age: median (range) & 51 & $74(46-88)$ & $71(41-88)$ & 0.39 \\
\hline Leukocyte count: median (range) & 51 & $30(6-188)$ & $15(2.8-26.4)$ & 0.006 \\
\hline Haemoglobin level (g/dL): median (range) & 50 & $10(8.1-14.1)$ & $12.5(7.4-16.2)$ & 0.03 \\
\hline MCV: median (range) & 35 & $92(86-106)$ & $93(79-101)$ & 0.33 \\
\hline Neutrophil count (G/L): median (range) & 41 & $15(1.5-41)$ & $2(0.1-12.9)$ & 0.07 \\
\hline Blood monocyte count (G/L): median (range) & 50 & $4.65(1-60)$ & $2(1-46)$ & 0.005 \\
\hline Platelets count (G/L): median (range) & 50 & $117.5(34-420)$ & $208(39-660)$ & 0.07 \\
\hline Bone marrow blasts (\%): median (range) & 51 & $7(2-18)$ & $6(1-14)$ & 0.11 \\
\hline $\begin{array}{l}\text { Bone marrow monocytes (\%): median } \\
\text { (range) }\end{array}$ & 50 & $20(6-35)$ & $15(3-45)$ & 0.04 \\
\hline MP-CMML & 30 & 19 & 11 & \multirow{2}{*}{0.03} \\
\hline MD-CMML & 21 & 6 & 15 & \\
\hline No acute transformation & 51 & 14 & 26 & \multirow{2}{*}{0.0005} \\
\hline Acute transformation & 51 & 11 & 0 & \\
\hline MP-CMML & $\begin{array}{l}\text { Number of } \\
\text { patients }\end{array}$ & ASXL1 mutated & ASXL1 unmutated & $p$ value \\
\hline Sex ratio & & 2.8 & 0.8 & 0.25 \\
\hline Age: median (range) & 30 & $74(55-88)$ & $70.5(42-87)$ & 0.13 \\
\hline Leukocyte count: median (range) & 30 & $35(6-188)$ & $17(15-26.5)$ & 0.08 \\
\hline Haemoglobin level (g/dL): median (range) & 29 & $11(8.1-12.5)$ & $11.5(8.5-15.2)$ & 0.03 \\
\hline MCV: median (range) & 21 & $92(80-106)$ & $88.5(74-101)$ & 0.11 \\
\hline Neutrophil count (G/L): median (range) & 26 & $25(7-41)$ & $10(7-12.9)$ & 0.54 \\
\hline Blood monocyte count (G/L): median (range) & 30 & $10(1-60)$ & $4.5(1.2-46)$ & 0.04 \\
\hline Platelets count (G/L): median (range) & 29 & $118(34-420)$ & $272(57-660)$ & 0.002 \\
\hline Bone marrow blasts (\%): median (range) & 30 & $7(2-16)$ & $6(2-14)$ & 0.54 \\
\hline $\begin{array}{l}\text { Bone marrow monocytes (\%): median } \\
\text { (range) }\end{array}$ & 29 & $25(6-35)$ & $14(3-45)$ & 0.16 \\
\hline MD-CMML & $\begin{array}{l}\text { Number of } \\
\text { patients }\end{array}$ & ASXL1 mutated & $A S X L 1$ unmutated & $p$ value \\
\hline Sex ratio & 21 & 5 & 1.8 & 0.75 \\
\hline Age: median (range) & 21 & $76.5(46-83)$ & $75(41-88)$ & 0.9 \\
\hline Leukocyte count: median (range) & 21 & $8.9(4-12)$ & $7.1(2.8-12.8)$ & 0.6 \\
\hline Haemoglobin level (g/dL): median (range) & 21 & $12(8.9-14.1)$ & $14(7.4-16.2)$ & 0.77 \\
\hline MCV: median (range) & 13 & $89(86-100)$ & $93.5(91-101)$ & 0.46 \\
\hline Neutrophil count (G/L): median (range) & 19 & $5(1.5-7)$ & $7.1(0.1-7.7)$ & 0.15 \\
\hline Blood monocyte count (G/L): median (range) & 21 & $1.3(1-4.5)$ & $1.4(1-2.6)$ & 0.55 \\
\hline Platelets count (G/L): median (range) & 21 & $122(43-414)$ & $130(39-399)$ & 0.5 \\
\hline Bone marrow blasts (\%): median (range) & 21 & $7(4-18)$ & $5(4-13)$ & 0.2 \\
\hline $\begin{array}{l}\text { Bone marrow monocytes (\%): median } \\
\text { (range) }\end{array}$ & 21 & $16(10-20)$ & $15(10-13)$ & 0.83 \\
\hline
\end{tabular}

MCV: mean cell volume; In bold: significant $p$ value

\section{unmutated CMML patients.}




\section{Legends to the figure.}

Fig 1. Kaplan-Meier overall survival curves for all CMML patients (A) and according to $A S X L 1$ mutational status (B). The number of patients at risk over time is shown beneath each panel. (C) Cumulative incidence of progression to acute myeloid leukaemia for all patients (C) and according to $A S X L 1$ mutational status (D). 


\begin{tabular}{|c|c|c|c|c|c|c|c|c|c|c|c|c|c|c|c|c|c|c|c|}
\hline & Case & $\begin{array}{c}\text { Sex/Age } \\
\text { (years) }\end{array}$ & Diagnosis & $\begin{array}{c}\text { RuNX1 } \\
\text { (exons 1-8) }\end{array}$ & $\begin{array}{c}\text { TET2 } \\
\text { (exons 3-11) }\end{array}$ & $\begin{array}{l}\text { ASXL1 } \\
\text { (exon 12) }\end{array}$ & $\begin{array}{l}\text { NPM1 } \\
\text { (exon 12) }\end{array}$ & $\begin{array}{c}W T 1 \\
\text { (exons } 7,9 \text { ) }\end{array}$ & $\begin{array}{c}\mathrm{CBL} \\
\text { (exons } 8,9)\end{array}$ & $\begin{array}{l}\text { FLT3 } \\
\text { ITDTKD }\end{array}$ & $\begin{array}{l}\text { JAK2 } \\
\text { (V617F) }\end{array}$ & 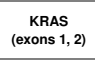 & $\begin{array}{l}\text { NRAS } \\
\text { (exons 1, 2) }\end{array}$ & 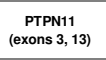 & $\begin{array}{l}\text { IDH1 } \\
\text { (exon 4) }\end{array}$ & $\begin{array}{l}\mathrm{IDH}_{2} \\
\text { (exon 4) }\end{array}$ & $\begin{array}{c}\text { Number of } \\
\text { attered genes }\end{array}$ & Karyotype & acGH \\
\hline$?$ & HD-0176 & M/42 & MP-CMML1 & no & no & no & no & no & no & no & no & no & no & no & no & no & 0 & 46,XY[20] & gain 7 p21 (AHR), Xp22 (SHзKВР1) \\
\hline 2 & HD-0182 & $F / 74$ & MP-CMML1 & no & no & no & no & no & no & no & no & no & p.Giy12Asp & no & no & no & 1 & $45, X,-X ?[20]$ & $\operatorname{loss} x$ \\
\hline 3 & HD-0200 & M/71 & MP-CMML1 & no & no & no & no & no & no & no & no & p.Ala146Val & no & no & no & no & 1 & 46,XY[20] & по CNA \\
\hline 4 & HD-0201 & M/87 & MP-CMML1 & no & no & p.Leu1266Histsx9 & no & no & no & no & no & 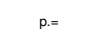 & p.Ala157Gly & no & no & no & 2 & 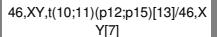 & no CNA \\
\hline 5 & HD-0223 & M/85 & MP-CMML1 & no & splicing defect & p.Arg1068x & no & no & p.Phe418Ser (hom) & no & no & no & no & nd & no & no & 3 & $46, X Y[20]$ & $\begin{array}{l}\text { loss } 13914 \text { (RB1), } 159211,15222 \text { (DAPK2), gain } \\
\text { Xp222 }\end{array}$ \\
\hline 6 & HD-0228 & M/70 & MP-CMML1 & no & p.TTp198X & p. Thr836LeutsX2 (nc) & no & no & no & no & no & p.Giy2Ser & no & no & no & no & 3 & 46,XY[20] & no CNA \\
\hline 7 & HD-0229 & M/87 & MP-CMML2 & no & p.Gint191X & no & no & no & no & no & no & no & no & na & no & no & 1 & 46,XY[20] & no CNA \\
\hline 8 & HD-0257 & $\mathrm{F} / 71$ & MP-CMML1 & no & no & no & no & no & no & no & no & no & no & nа & no & p.Arg140Gin & 1 & $46, x \times[20]$ & no CNA \\
\hline $\begin{array}{l}9 \\
10\end{array}$ & HD-0272 & $F / 79$ & MP-CMML1 & no & $\begin{array}{l}\text { p.Arg1452X } \\
\text { p.Tyrr1560LeưfsX18 }\end{array}$ & p.Gly646TrpfsX12 & no & no & no & no & no & no & p. Gly13Asp & na & no & no & 3 & $46, x \times[20]$ & no CNA \\
\hline 10 & HD-0273 & M/76 & MP-CMML1 & no & p.Giy1361Ser & p.Lys888GGuts $\times 6$ & no & no & no & no & no & no & no & па & no & p.Arg140Gin & 3 & 46,XY[20] & по CNA \\
\hline 11 & HD-0316 & M/65 & MP-CMML1 & p.Prou25Leu & na & па & no & na & na & na & no & no & no & p.Asp61Tyr & na & па & 2 & $46, X Y[20]$ & losses 3922-24 (EPHB1, NEK11, MRAS...) \\
\hline 12 & HD-0318 & M/69 & MP-CMML1 & p.Arg166x & no & p. $\operatorname{Gin} 768 \mathrm{X}$ & na & na & na & na & no & no & no & no & nа & na & 2 & 46,XY,del(20)(a1 191313/20] & loss 2091-q13 \\
\hline 13 & HD-0320 & $\mathrm{F} / 74$ & MP-CMML2 & splicing defect & p.Arg1 1404X & p.Gly646Trpfs X12 & no & no & no & no & no & no & no & p.Ala72Thr & no & no & 4 & $47, \mathrm{XX},+8[20]$ & tri 8 \\
\hline 14 & HD-0321 & M/55 & MP-CMML2 & p.Arg166x & no & p.His630Profos X66 & no & no & na & no & no & no & no & no & no & no & 2 & 46,XY[20] & loss 3p23 (GLB1, CRTAP) \\
\hline 15 & HD-0322 & $F / 61$ & MP-CMML1 & no & no & no & no & no & no & no & no & no & no & no & no & no & 0 & $46, x \times[20]$ & no CNA \\
\hline 15 & HD-0327 & $F / 72$ & MP-CMML1 & p.Ty:377LLufsX223 & p.Cys 1937тр & p. Gly646 TrpfsX12 & no & no & no & no & no & no & p.Giy12Asp & no & no & no & 4 & $47, X X+8[20]$ & tris \& loss 7q11 (CALN1) \\
\hline 16 & HD-0366 & M/78 & MP-CMML1 & no & no & p.Serra6Ginstsx5 (nc) & na & na & na & na & no & no & no & no & na & na & 1 & 46,XY[20] & по CNA \\
\hline 17 & HD-0367 & $\mathrm{F} / 70$ & MP-CMML2 & no & no & no & no & no & no & ITD & no & no & no & no & no & no & 1 & 46,XX,inv(11)(1915922)[20] & no CNA \\
\hline 18 & HD-0370 & M/70 & MP-CMML2 & no & no & p. Thr 271 LysfisX10 (nc) & no & no & no & no & no & no & no & no & no & no & 1 & 46,XY[20] & no CNA \\
\hline 19 & HD-0376 & $\mathrm{F} / 65$ & MP-CMML2 & no & no & no & no & no & no & no & no & no & no & no & no & no & 0 & $46, X X,(1 ; 3)(p 36 ; ; q 21)([20]$ & no CNA \\
\hline 20 & HD-0397 & $\mathrm{F} / 71$ & MP-CMML1 & no & no & no & no & no & no & no & no & no & no & na & no & no & 0 & $46, \mathrm{XX}[20]$ & nа \\
\hline 21 & HD-0398 & M/62 & MP-CMML1 & no & no & p.Gly646Trpssx12 & no & no & no & no & no & no & no & na & no & no & 1 & $47, X Y,+19[177 / 46, X Y[3]$ & tri 19 \\
\hline 21 & HD-0399 & M/74 & MP-CMML1 & p.Ser141Leu & no & p.Gly646TrpisX12 & no & no & p.Cys396Tyr & no & no & no & no & no & no & no & 3 & 46,XY[20] & no CNA \\
\hline 22 & HD-0404 & $\mathrm{M} / 88$ & MP-CMML2 & p.Arg201X & p.Asn15811llefsX17 & p.His630Profs X66 & no & no & no & no & no & no & no & na & no & no & 3 & $47, X Y,+21[20]$ & tri 21 \\
\hline 23 & HD-0485 & M/63 & MP- CMML 2 & p.Arg320X & p.Leut252Pro & p.Gly646Tpts X12 & no & no & no & no & no & no & no & nа & no & no & 3 & 46,XY[20] & no CNA \\
\hline $\begin{array}{l}24 \\
25\end{array}$ & HD-0627 & $F / 87$ & MP-CMML1 & no & no & p.Arg1068X & no & no & p.Cys404Tyr (hom) & no & no & no & no & na & no & no & 2 & 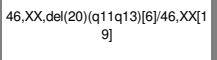 & no $\mathrm{CNA}$ \\
\hline $\begin{array}{l}25 \\
26\end{array}$ & HD-0669 & M/88 & MP-CMML1 & no & no & p.Ala611Argts $\times 8$ & no & no & no & no & no & no & no & nа & no & no & 1 & $46, X Y[20]$ & по CNA \\
\hline 27 & HD-0671 & $F / 71$ & MP-CMML1 & p.lysi 10Arg & no & p.Tyr591x & no & no & no & no & no & no & no & na & no & no & 2 & $47, X X,+1998 / 466, X X[12]$ & loss 17911 (NF1), tri 19 \\
\hline 28 & HD-0707 & M/85 & MP-CMML1 & no & no & no & no & no & p. Tyri371His & no & no & no & no & na & no & no & 1 & $46, X Y[20]$ & no $\mathrm{CNA}$ \\
\hline 0 & HD-0715 & M69 & MP-CMML1 & no & no & no & no & no & no & no & no & no & no & na & no & no & 0 & $46, X Y[20]$ & na \\
\hline 29 & HD-0723 & M/83 & MP-CMML1 & no & no & p. 12131 lets $\times 3$ & no & no & no & no & no & no & p.Gly12Val & na & no & p.Arg140Gin & 3 & 46,XY[20] & по CNA \\
\hline 30 & HD-0178 & M/88 & MD-CMML1 & no & no & no & no & no & no & no & no & no & no & no & no & p.Arg140Gin & 1 & $46, X Y, \mathrm{del}(20)(\mathrm{q} 11 \mathrm{q} 13)[20]$ & loss 13q14 (RB1), 20q11-q13 \\
\hline 31 & HD-0197 & M/59 & MD-CMML1 & p.Arg320X & no & no & na & na & na & na & no & no & no & no & na & na & 1 & 46,XY[20] & no CNA \\
\hline $\begin{array}{l}32 \\
33\end{array}$ & HD-0206 & M/73 & MD-CMML2 & no & deletion & p.Asp879GlufsX7 & no & no & no & no & no & no & no & па & no & p.Arg172Lys & 3 & 46,XY[20] & loss 4q24 (TET2) \\
\hline 34 & $\mathrm{HD}-0230$ & M/83 & MD-CMML1 & no & no & P. His6300ProlsX666 & no & no & no & no & no & no & no & na & no & no & 1 & $46, X Y[20]$ & по CNA \\
\hline 34 & HD-0242 & $F / 82$ & MD-CMML1 & no & no & no & no & no & no & no & no & no & no & па & no & no & 0 & $46, \times \times[25]$ & no CNA \\
\hline 35 & HD-0254 & $F / 83$ & MD-CMML2 & no & no & no & no & no & no & no & no & no & no & па & no & no & 0 & $46, X \times[20]$ & loss $17 q 11$ (NF1) \\
\hline 36 & HD-0271 & $F / 82$ & MD-CMML1 & no & no & p.Pro1263GinfsX17 & no & no & no & no & no & no & no & na & no & no & 1 & $46, x \times[20]$ & по CNA \\
\hline 37 & HD-0280 & M/8 & MD-CMML1 & no & p.Ser 1 189Valts $\times 37$ & no & no & no & no & no & no & no & no & na & no & no & 1 & $45, X_{-}, Y[19] / 46, X Y[1]$ & loss Y \\
\hline 38 & HD-0328 & M/73 & MD-CMML1 & no & p.GIy355Asp (hom) & p.Gly646TrpisX12 & no & no & p.Cys404Tyr & no & no & no & no & no & no & no & 3 & 46,XY[20] & no CNA \\
\hline 30 & HD-0330 & M/76 & MD-CMML1 & p.G1y50Ginis X4 & na & na & na & na & na & na & no & no & no & no & na & na & 1 & $46, X Y[20]$ & nо $\mathrm{CNA}$ \\
\hline 39 & HD-0355 & M/65 & MD-CMML1 & no & p.Cys 1289Phe & no & no & no & no & no & no & no & no & no & no & no & 1 & $46, X Y[20]$ & nо CNA \\
\hline 40 & HD-0372 & $M / 60$ & MD-CMML1 & no & no & no & no & no & no & no & no & no & no & no & no & no & 0 & 46,XY[20] & по CNA \\
\hline 41 & HD-0380 & $F / 82$ & MD-CMML1 & no & p.Gin1414X & no & no & no & no & no & no & no & no & no & no & no & 1 & $46, x \times[20]$ & по CNA \\
\hline 42 & HD-0388 & $\mathrm{F} / 71$ & MD-CMML1 & p. Met133le & p.Leu1721Phefs $\times 8$ & no & no & no & no & no & no & no & no & nа & no & no & 2 & $46, \times \times[20]$ & no CNA \\
\hline 43 & HD-0396 & $\mathrm{M} / 70$ & MD-CMML1 & no & p.Ser354x & no & no & no & no & no & no & no & no & nа & no & no & 1 & $46, X Y[20]$ & по CNA \\
\hline 44 & HD-0638 & $F / 68$ & MD-CMML1 & no & p.Leu1394TrpfsX54 & no & no & no & no & no & no & no & no & nа & no & no & 1 & $46, \times \times[20]$ & no CNA \\
\hline 45 & HD-0660 & M/80 & MD-CMML1 & no & no & p.Arg693x & no & no & no & no & no & no & no & na & no & no & 1 & 46,XY[20] & no $\mathrm{CNA}$ \\
\hline 45 & HD-0703 & M74 & MD-CMML1 & no & no & no & no & no & no & no & no & no & no & nа & no & no & 0 & 46,XY[20] & no $\mathrm{CNA}$ \\
\hline 46 & HD-0711 & M79 & MD-CMML1 & no & p. Gin649x & no & no & no & no & no & no & no & no & na & no & no & 1 & 46,XY[20] & по CNA \\
\hline 47 & HD-0712 & $M / 41$ & MD-CMML1 & no & no & no & no & no & no & no & no & no & no & nа & no & no & 0 & $46, X Y[20]$ & по CNA \\
\hline 48 & HD- 0743 & M/68 & MD-CMML1 & no & no & no & no & no & no & no & no & no & no & na & no & no & 0 & $46, X Y[20]$ & no CNA \\
\hline
\end{tabular}



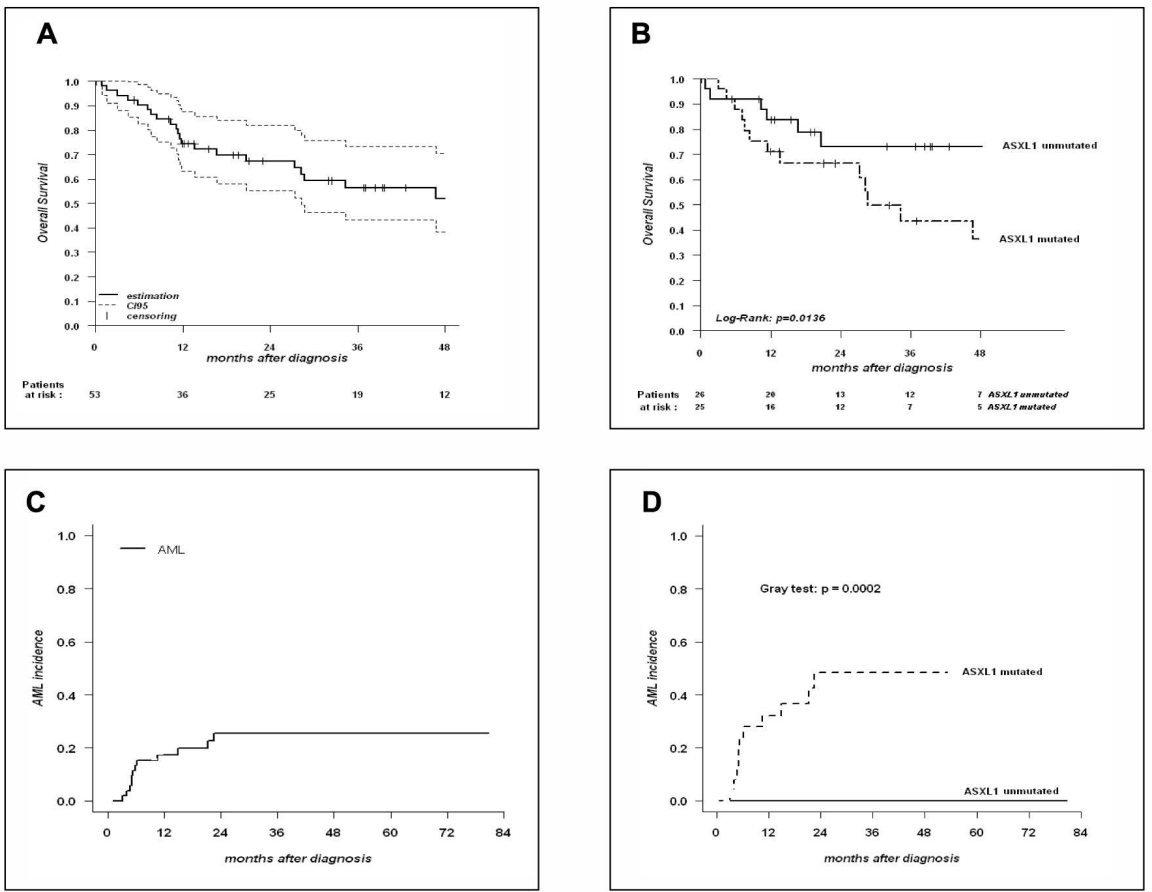

Kaplan-Meier overall survival curves for all CMML patients $(A)$ and according to ASXL1 mutational status (B). The number of patients at risk over time is shown beneath each panel. (C) Cumulative incidence of progression to acute myeloid leukaemia for all patients (C) and according to ASXL1 mutational status (D). 


\section{Page 25 of 25}

British Journal of Haematology

\begin{tabular}{|c|c|c|c|c|c|c|c|c|c|c|}
\hline \multirow[t]{2}{*}{ Patient } & \multirow[t]{2}{*}{$\begin{array}{l}\text { Sex/Age } \\
\text { (years) }\end{array}$} & \multirow[t]{2}{*}{$\begin{array}{c}\text { Diagnosis } \\
\text { (WHO) }\end{array}$} & \multirow{2}{*}{$\begin{array}{l}\text { Antecedent of } \\
\text { chemotiterapy or } \\
\text { radiotherapy }\end{array}$} & \multirow[t]{2}{*}{ Organomegaly } & $\begin{array}{r}\text { Perip } \\
\text { WBC }(G L L)\end{array}$ & Peripheral blood & \multicolumn{2}{|c|}{ Bone marrow } & \multirow[t]{2}{*}{$\begin{array}{c}\text { Acute } \\
\text { transtormation }\end{array}$} & \multirow[t]{2}{*}{$\begin{array}{c}\text { Treatment at } \\
\text { sampling }\end{array}$} \\
\hline & & & & & \multicolumn{2}{|l|}{$\begin{array}{l}\text { MP-CMML } \\
\end{array}$} & & & & \\
\hline HD-0176 & M42 & CMML1 & no & no & 17.3 & 1.2 & 2 & 12 & no & $\begin{array}{ll}\text { none } \\
\text { non }\end{array}$ \\
\hline HD-0182 & $F / 74$ & СMML 1 & no & no & 16.0 & 1.9 & 3 & 3 & no & none \\
\hline HD-0200 & M71 & СMML1 & no & no & 22 & 7 & 8 & 32 & no & TA \\
\hline HD-0201 & M86 & CMML 1 & nd & splenomegaly & 116.8 & 40 & 7 & nd & yes & none \\
\hline HD-0223 & M85 & CMML 1 & no & no & 27.9 & 4.9 & 2 & 18 & no & none \\
\hline HD.0228 & M70 & сммL 1 & no & $\begin{array}{l}\text { splenomegaly } \\
\text { henatomegaly }\end{array}$ & 32 & 5 & 5 & 12 & no & TA \\
\hline HD-0229 & M87 & СмML2 & yes & no & 16 & 3.2 & 12 & 22 & no & none \\
\hline HD-0257 & $F / 71$ & CMML 1 & no & no & 16.3 & 2 & 5 & 17 & no & EPO \\
\hline HD-0272 & F/79 & CMML 1 & no & no & 10 & 3 & 3 & 7 & no & hydrea \\
\hline HD-0273 & M76 & CMML2 & no & no & 32.4 & 15 & 9 & ${ }^{23}$ & no & TA \\
\hline HD-0316 & M65 & CMML2 & no & no & 37 & 5.7 & 15 & 12 & no & none \\
\hline HD-0318 & M69 & смML 1 & yes & $\begin{array}{l}\text { splenomegaly } \\
\text { hepatomegaly }\end{array}$ & 30 & 1 & 3 & 6 & yes & none \\
\hline HD-0з20 & $F / 74$ & СмМL2 & no & no & 43.5 & 14.5 & 15 & 16 & yes & none \\
\hline HD-0321 & M55 & CMML2 & no & no & 55 & 14.8 & 15 & 35 & yes & none \\
\hline HD-0322 & $F / 61$ & CMML 1 & no & no & 38 & 3.5 & 3 & 6 & no & hydrea \\
\hline HD-0327 & $F / 72$ & CMML1 & no & no & 188 & ${ }^{43}$ & 9 & 27 & yes & none \\
\hline HD-0366 & M78 & CMML 1 & no & no & 13.2 & 4.6 & 3 & 33 & no & TA \\
\hline HD-0367 & $F / 70$ & CMML2 & yes & no & 64 & 46 & 14 & 40 & no & none \\
\hline HD-0370 & M70 & СMML2 & no & splenomegaly & 25.4 & 2.5 & 18 & 10 & yes & TA \\
\hline HD-376 & $F / 65$ & СMML2 & yes & no & 18 & 2.9 & 11 & 14 & no & transtusions \\
\hline HD-0397 & $F / 72$ & СмML 1 & no & no & 26.5 & 4.7 & 6 & 45 & no & none \\
\hline HD-0398 & M59 & смML 1 & no & splenomegaly & 36 & 3 & 6 & 20 & yes & hydrea \\
\hline HD-0399 & M74 & смML 1 & no & $\begin{array}{l}\text { splenomegaly. } \\
\text { nicroadenomenaly }\end{array}$ & 6 & 2 & 6 & 30 & no & hydrea + EPO \\
\hline HD-0404 & M89 & смML1 & no & no & 35 & 12 & 16 & 34 & no & none \\
\hline HD-0485 & W63 & CMML2 & no & no & 14.7 & 4.4 & 12 & 22 & no & none \\
\hline HD-0627 & $F / 86$ & CMML 1 & no & splenomega & 41.7 & ${ }_{10}$ & 5 & 28 & no & none \\
\hline HD-0669 & M88 & СMML 1 & no & no & 28.4 & 6.8 & 8 & 37 & no & TA \\
\hline HD-0671 & $F / 71$ & CMML2 & no & no & 35.9 & 4.7 & 15 & 30 & yes & none \\
\hline HD-0707 & M85 & СMML 1 & no & no & 11.8 & 2.25 & 4 & 28 & no & hydrea \\
\hline HD-0715 & W69 & СMML1 & no & no & 15 & 1.4 & 7 & 6 & no & none \\
\hline HD-0723 & M83 & СмML 1 & no & no & 17.9 & 2.87 & 5 & 12 & yes & $T A$ \\
\hline \multicolumn{11}{|c|}{ MD-CMML } \\
\hline HD-0178 & M88 & CMML1 & no & no & 6.9 & 1.5 & 7 & 22 & $\begin{array}{l}\text { no } \\
\text { no }\end{array}$ & none \\
\hline HD-0197 & M59 & СмML 1 & no & atomega & 11.4 & 2.6 & 6 & 23 & no & none \\
\hline HD-0206 & M73 & СMML2 & no & no & 8.8 & 1.2 & 18 & 13 & yes & none \\
\hline HD-0230 & M86 & СмML1 & no? & no & 10.4 & 1.78 & 8 & 20 & no & none \\
\hline HD-0242 & $F / 82$ & смML1 & no & no & 6.9 & 1.9 & 5 & 10 & no & none \\
\hline HD-0254 & $F / 83$ & СмML2 & no & no & 9.1 & 1 & 13 & 15 & no & none \\
\hline HD-0271 & $F / 82$ & СмML1 & no & no & 9 & 1.35 & 6 & 18 & no & none \\
\hline HD-0280 & M79 & СMML1 & no & no & 7.1 & 1.3 & 7 & 18 & no & TA \\
\hline HD-0328 & M73 & CMML1 & no & no & 7.4 & 4.5 & 4 & 20 & no & none \\
\hline HD-0330 & M76 & СмML1 & no & Datomeg & 5.1 & 1.79 & 7 & 16 & no & none \\
\hline HD-0355 & M65 & СмML1 & yes & no & 4 & 1 & 7 & 12 & no & none \\
\hline HD-0372 & M60 & СмML 1 & no & no & 12 & 1.1 & 4 & 10 & no & none \\
\hline HD-0380 & M82 & СмML 1 & no & $\begin{array}{l}\text { splenomegaly } \\
\text { polyadenomegaly }\end{array}$ & 5.4 & 1.1 & 4 & 10 & no & none \\
\hline HD-0388 & $F / 71$ & CMML 1 & no & no & 7.1 & 1.15 & 6 & 22 & no & none \\
\hline HD-0396 & M79 & CMML 1 & no & nd & 10.3 & 2 & 4 & 11 & no & none \\
\hline HD.0638 & $F / 68$ & CMML1 & no & no & 5.1 & 1.38 & 8 & 18 & no & none \\
\hline HD-0660 & M80 & CMML1 & no & adenomegaly & 6.1 & 1.7 & 5 & 15 & no & 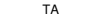 \\
\hline HD-0703 & M74 & CMML1 & no & no & 12.8 & ${ }^{1.42}$ & 1 & 4 & no & none \\
\hline HD-0711 & M78 & CMML1 & no & no & 9.74 & 1.35 & 3 & 19 & no & transtusions \\
\hline HD-0712 & M41 & CMML1 & no & no & 9.8 & 1 & 3 & 6 & no & none \\
\hline HD-0743 & M68 & CMML 1 & no & no & 2.8 & 2 & 7 & 19 & no & none \\
\hline HD.0755 & M46 & CMML1 & yes & no & 9.8 & 2.4 & 4 & 12 & yes & none \\
\hline
\end{tabular}

